\title{
Berbagi pengetahuan sebagai pembelajaran organisasi di Perpustakaan Nasional Republik Indonesia
}

\author{
Hilarius Nugroho Adiprabowo1, Pawit M. Yusup², Rully Khairul Anwar \\ 1Perpustakaan Sekolah Kolese Kanisius \\ Jl. Menteng Raya No. 64, Kebon Sirih, Menteng, Jakarta Pusat, 10340 \\ 2, 3Program Studi Ilmu Perpustakaan, Universitas Padjadjaran \\ Jl. Raya Bandung-Sumedang KM. 21, Jatinangor, Sumedang, Jawa Barat, 45363 \\ Email: 1nugroho.hilarius@gmail.com, 2pawit.m.yusup@unpad.ac.id, 3rully.khairul@unpad.ac.id
}

Received: January 2019; Accepted: December 2019; Published: December 2019

\begin{abstract}
An organization shares knowledge as an organizational learning medium so the organization can continue to grow and update information owned by individuals. This study discussed the knowledge sharing process in organizational learning at the National Library of the Republic of Indonesia (PERPUSNAS). This research was conducted to determine the process of applying knowledge sharing, which included aspects of knowledge sharing behavior and the benefits of its application in organizational learning in PERPUSNAS Preservation and Conservation Sub-Division. This qualitative research used a case study approach. Data were collected through observation, interviews, literature study, and documentation. Based on study results, the knowledge sharing process in organizational learning at PERPUSNAS consisted of four aspects, including aspects of subjective norms, attitudes, aspects of behavioral control, and social networking. Librarians in the subjective norm, always directly accepted new policies from superiors. Regarding attitude, librarians succeeded in bringing the organizational direction in a better and non-monotonous direction. Regarding the behavioral control aspect, PERPUSNAS maximized staff potentials by giving the freedom to work outside the sub-field. Also, social networking issues added to the librarian's convenience when sharing knowledge through social media groups, such as WhatsApp. Knowledge sharing activities at PERPUSNAS become a means to improve individual competencies to become better human resources.
\end{abstract}

Keywords: Knowledge sharing; Organizational learning; National Library of the Republic of Indonesia (PERPUSNAS)

\begin{abstract}
Abstrak
Sebuah organisasi melakukan berbagi pengetahuan sebagai media pembelajaran organisasi agar organisasi tersebut dapat terus berkembang dan memperbarui informasi pengetahuan yang dimiliki individu. Penelitian ini membahas mengenai proses berbagi pengetahuan dalam pembelajaran organisasi di Perpustakaan Nasional Republik Indonesia (PERPUSNAS), yang bertujuan mengetahui proses penerapan berbagi pengetahuan yang meliputi aspek perilaku berbagi pengetahuan dan manfaat penerapannya dalam pembelajaran organisasi pada Sub Bidang Perawatan dan Perbaikan Bahan Pustaka PERPUSNAS. Metode penelitian yang digunakan ialah studi kasus melalui pendekatan kualitatif. Pengumpulan data dilakukan melalui observasi, wawancara, studi pustaka, dan dokumentasi. Berdasarkan hasil penelitian, proses berbagi pengetahuan dalam pembelajaran organisasi di PERPUSNAS meliputi empat aspek, di antaranya aspek norma subjektif, sikap, aspek kontrol perilaku, dan aspek jaringan sosial. Pustakawan dalam norma subjektif, selalu menerima kebijakan yang baru dari atasan secara langsung di PERPUSNAS. Adapun dalam sikap, pustakawan telah berhasil membawa arah organisasi ke arah yang semakin baik dan tidak monoton. PERPUSNAS dalam aspek kontrol perilaku telah memaksimalkan potensi staf dengan memberikan kebebasan untuk berkarya di luar sub bidang. Selain itu, aspek jaringan sosial telah menambah kemudahan pustakawan ketika berbagi pengetahuan melalui grup media sosial, seperti WhatsApp. Kegiatan berbagi pengetahuan di PERPUSNAS menjadi sarana untuk meningkatkan kompetensi individu agar menjadi sumber daya manusia yang semakin baik.
\end{abstract}

Kata Kunci: Berbagi pengetahuan; Pembelajaran organisasi; Perpustakaan Nasional Republik Indonesia (PERPUSNAS) 


\section{PENDAHULUAN}

Kemajuan teknologi informasi dan komunikasi saat ini menuntut setiap manusia memiliki kemampuan tertentu dalam mengembangkan potensi diri. Salah satu kemampuan tersebut merupakan pengetahuan yang berasal dari interaksi di lingkungan sekitar dalam kehidupan sehari-hari. Terkadang pengetahuan tersebut hanya terpendam dalam diri saja (tacit knowledge) sehingga perlu didokumentasikan dan disebarkan kepada orang lain (explicit knowledge).

Pengetahuan merupakan salah satu anugerah dari Sang Pencipta yang dimiliki setiap makhluk hidup, termasuk manusia. Pengetahuan itu tidak dapat terlihat wujudnya, bersifat abstrak, dan tidak terbatas. Pengetahuan baru dapat dirasakan manfaatnya ketika alih bentuk ke dalam sebuah tulisan atau dalam keahlian.

Menurut Dragicevic, Ullrich, Tsui, and Gronau (2019) berpendapat bahwa, "Knowledge can be deconstructed into discrete units with an implication that knowledge is an artifact that people or machines can possess." Pengetahuan dapat ditata ulang menjadi unit terpisah dengan implikasi bahwa pengetahuan adalah artefak yang dapat dimiliki orang atau mesin. Pengetahuan dapat diwujudkan, diciptakan bersama individu, dan tidak dapat dipisahkan melalui interaksi berkelanjutan. Dragicevic et al. (2019) pun menambahkan bahwa keberhasilan berbagi pengetahuan bergantung pada kebutuhan pribadi, nilai, kepercayaan, pengetahuan, dan emosi.

Menurut Undang-Undang Nomor 43 Tahun 2007 tentang Perpustakaan, Perpustakaan Nasional merupakan, “Lembaga pemerintahan non-departemen yang melaksanakan tugas pemerintahan dalam bidang perpustakaan yang berfungsi sebagai perpustakaan pembina, rujukan, deposit, penelitian, pelestarian, dan pusat jejaring perpustakaan, serta berkedudukan di ibu kota negara"(Kementerian Pendidikan dan Kebudayaan, 2007). Perpustakaan Nasional Republik Indonesia didirikan pada tahun 1989 berdasarkan Keputusan Presiden nomor 11 tahun 1989. Pada pasal 19 dinyatakan bahwa, "Pusat Pembinaan Perpustakaan, Perpustakaan Nasional Departemen Pendidikan dan Kebudayaan dan Perpustakaan Wilayah di Provinsi merupakan satuan organisasi yang melaksanakan fungsi dan tugas perpustakaan nasional" (Tumanggor, 2018).

Berdasarkan pasal 19 tersebut, maka dapat ditafsirkan bahwa Perpustakaan Nasional Republik Indonesia merupakan gabungan dari tiga perpustakaan, yaitu Perpustakaan Museum Nasional yang semula merupakan koleksi Koninklijk milik Bataviaasch Genootschap van Kunsten Wetenschapen; Perpustakaan Sejarah, Politik, dan Sosial (semula perpustakaan Sticusa); Kantor Bibliografi Nasional, dan Perpustakaan Wilayah Daerah Khusus Ibu kota Jakarta.

Saat ini, Perpustakaan Nasional Republik Indonesia mempunyai gedung yang berlokasi di Jalan Salemba Raya Nomor 28A Jakarta dan di Jalan Medan Merdeka Selatan Nomor 11 Jakarta. Perpustakaan Nasional berdasarkan Pasal 21 Undang-Undang Republik Indonesia Nomor 43 Tahun 2007 memiliki beberapa tugas. Pertama, menetapkan kebijakan nasional, kebijakan umum, dan kebijakan teknis pengelolaan perpustakaan. Kedua, melaksanakan pembinaan, pengembangan, evaluasi, dan koordinasi 
terhadap pengelolaan perpustakaan. Ketiga, membina kerja sama dalam pengelolaan berbagai jenis perpustakaan. Keempat, mengembangkan standar nasional perpustakaan.

Terkait tugas tersebut, maka Perpustakaan Nasional Republik Indonesia melakukan pembagian kerja pada para staf ke dalam beberapa bidang dan sub bidang. Salah satunya yaitu Sub Bidang Perawatan dan Perbaikan Bahan Pustaka di bawah Bidang Konservasi. Pada Sub Bidang Perawatan dan Perbaikan Bahan Pustaka, para pustakawan melakukan berbagi pengetahuan dalam forum formal maupun non formal. Pustakawan melakukan forum formal berupa rapat atau forum diskusi, sedangkan kegiatan di luar forum, dapat dilakukan pada saat jam kerja atau saat para staf istirahat.

Para staf Sub Bidang Perawatan dan Perbaikan Bahan Pustaka Perpustakaan Nasional Republik Indonesia melakukan berbagi pengetahuan dalam proses mereka bekerja sehari-hari. Kegiatan tersebut diawali pukul 07.30 WIB, atau ketika para pustakawan sudah absen dan berkumpul di ruangan untuk kemudian mempersiapkan alat dan bahan untuk bekerja. Berbagi pengetahuan dilakukan melalui kegiatan diskusi atau bertukar pikiran dalam kurun waktu kerja, hingga pukul 16.00 WIB.

Kegiatan berbagi pengetahuan tidak hanya dilakukan para pustakawan Sub Bidang Perawatan dan Perbaikan Bahan Pustaka pada saat jam kerja, namun juga di masa senggang, seperti saat istirahat makan siang. Pada Sub Bidang Perawatan dan Perbaikan Bahan Pustaka terdapat pustakawan yang berjumlah sepuluh orang dengan satu kepala sub bidang, pustakawan senior dan pustakawan baru. Mereka bergabung bekerja di bagian ini memiliki kesamaan untuk memajukan sub bidang tersebut. Mereka berkomunikasi cenderung bersifat timbal balik. Mereka mengutarakan ide saat jam istirahat. Berbagi pengetahuan yang dilakukan pustakawan Sub Bidang Perawatan dan Perbaikan Bahan Pustaka membuat organisasi ini akan terus belajar untuk tetap hadir dan berkembang, dalam merawat dan memelihara koleksi bahan pustaka yang dimiliki oleh Perpustakaan Nasional Republik Indonesia.

Kegiatan berbagi pengetahuan di perpustakaan telah diteliti beberapa peneliti, salah satunya penelitian Prabowo (2016), mengenai manajemen pengetahuan para pustakawan di Perpustakaan UIN Sunan Kalijaga Yogyakarta. Hasil penelitiannya menunjukkan bahwa pustakawan sudah menerapkan manajemen pengetahuan cukup tinggi di perpustakaan. Namun, pustakawan masih memiliki kendala dalam penyelesaian masalah di perpustakaan. Pustakawan diperlukan koordinasi dan komunikasi dengan sesama pustakawan lainnya.

Sesuai rujukan ini, terlihat bahwa pustakawan belum bisa berbagi pengetahuan secara bebas. Pengetahuan masih dimiliki pustakawan tertentu. Pustakawan di Sub Bidang Perawatan dan Perbaikan Bahan Pustaka Perpustakaan Nasional Republik Indonesia, telah melakukan berbagi pengetahuan pada pustakawan lain. Mereka berinteraksi dan berkomunikasi satu sama lain. Hal ini yang menjadi pembeda antara penelitian Prabowo (2016) dengan penelitian yang sudah peneliti teliti. Pustakawan memegang peran penting dalam membuka komunikasi di organisasi 
tempat mereka bekerja. Dengan demikian, penelitian ini berfokus pada proses berbagi pengetahuan Pustakawan di Sub Bidang Perawatan dan Perbaikan Bahan Pustaka Perpustakaan Nasional Republik Indonesia.

\section{METODE PENELITIAN}

Penelitian ini bertujuan untuk mengetahui proses berbagi pengetahuan dalam Pembelajaran organisasi di Sub Bidang Perawatan dan Perbaikan Bahan Pustaka Perpustakaan Nasional Republik Indonesia. Metode yang digunakan untuk menunjang prinsip dan prosedur dalam usaha mencari informasi penelitian, yakni pendekatan kualitatif dengan metode penelitian studi kasus. Menurut Candrasari (2019), penelitian kualitatif dapat digunakan untuk memahami interaksi sosial melalui wawancara informan secara mendalam sehingga dapat ditemukan pola yang jelas. Wardiana, Khadijah, and Rukmana (2018) menyatakan bahwa, "Metode studi kasus dalam metode penelitian kualitatif ialah pendekatan yang mengidentifikasi pertanyaan penelitian yang menjadi topik penelitian." Peneliti harus memahami fenomena yang diteliti sehingga dapat menguraikan pertanyaan penelitian yang diajukan.

Adapun Harrison, Bricks, Franklin, and Mills (2017) dalam Wardiana et al. (2018) menulis, "Documents, records, interviews, 'detached' observations, participant observations, physical artefacts". Peneliti dalam melakukan pengumpulan data, melakukan observasi, wawancara, studi pustaka, dan dokumentasi. Kemudian, kami memilih 8 pustakawan sebagai informan berdasarkan waktu lamanya bekerja, yang meliputi 1 Kepala Sub
Bidang dan 7 orang pustakawan untuk pengumpulan informasi penelitian. Adapun pemilahan tersebut dilakukan untuk melihat lebih detail para pustakawan yang rutin membagikan pengetahuan pada staf yang lain.

\section{HASIL DAN PEMBAHASAN}

Perpustakaan Nasional Republik Indonesia sebagai lembaga induk perpustakaan di Indonesia telah merancang strategi pengembangan pustakawan dalam memajukan perpustakaan. Hal ini terletak pada pengetahuan koleksi perpustakaan dan Sumber Daya Manusia (SDM) perpustakaan. Pustakawan yang dapat menggerakan kedua hal ini melalui pengetahuan tiap individu yang berbeda. "Pustakawan yang mempunyai kompetensi komunikasi yang baik akan mampu memperoleh dan mengembangkan tugas yang diembannya, sehingga tingkat kinerja pustakawan menjadi semakin baik" (Batubara, 2011). Maka, pustakawan dapat berbagi pengetahuan dengan orang lain agar menjadi kekayaan kelompok bersama.

Berbagi pengetahuan merupakan salah satu langkah sederhana untuk mempertahankan ciri khas organisasi, termasuk juga mengembangkannya melalui anggota organisasi yang ada. Hal ini didukung pernyataan narasumber.

“Di kita itu kalau gak ngelakuin berbagi pengetahuan gak bakal berkembang, Mas. Nanti perpustakaan lain jadi gak percaya lagi sama kita. Cara kita berbagi pengetahuan dikembalikan lagi ke tiap sub bidang yang ada." (David, wawancara, July 11, 2019).

Proses berbagi pengetahuan juga dilakukan Sub Bidang Perawatan dan 
Perbaikan Bahan Pustaka dengan tujuan untuk mengembangkan dan memajukan Perpustakaan Nasional Republik Indonesia. Berbagi pengetahuan menjadi solusi bagi Sub Bidang Perawatan dan Perbaikan Bahan Pustaka untuk bersamasama berkembang dari pengetahuan baru tersebut. Tujuannya sendiri adalah untuk membangun organisasi yang dapat dikembangkan mulai dari dalam lembaga, misalnya pengetahuan yang sebelumnya dimiliki satu pustakawan maka dapat dibagikan sama rata pada pustakawan lainnya.

Proses berbagi pengetahuan di Sub Bidang Perawatan dan Perbaikan Bahan Pustaka terjadi secara alamiah. Tanpa disadari, para pustakawan dalam melakukan setiap pekerjaan di Sub Bidang Perawatan dan Perbaikan Bahan Pustaka telah melakukan proses berbagi pengetahuan. Kegiatan proses berbagi pengetahuan sangat penting. Hal ini dalam kegiatan preservasi berkaitan dengan teori yang dikemukakan Nonaka and Takeuchi (1995) tentang model siklus berbagi pengetahuan (SECI) yang menjelaskan bahwa siklus berbagi pengetahuan terdiri dari, sosialisasi (socialization), externalization, kombinasi (combination), dan internalisasi (internalization). Proses berbagi pengetahuan pada kegiatan preservasi di Sub Bidang Perawatan dan Perbaikan Bahan Pustaka dapat terlihat dalam model di atas.

Pada tahap sosialisasi, terjadi penyebaran pengetahuan dari satu pustakawan pada pustakawan lain melalui interaksi dan komunikasi di kehidupan sehari-hari, seperti pertanyaan mengenai takaran campuran bahan kimia yang tepat untuk digunakan dalam proses penetralan keasaman kertas (deasidifikasi). Pada tahap externalization, pustakawan yang mempunyai pengetahuan baru akan membagikannya ke pustakawan di lingkungan sub bidang, contohnya saat pustakawan yang baru menyelesaikan pendidikan ke jenjang yang lebih tinggi. Pustakawan tersebut akan memunculkan banyak ide, gagasan, dan konsep yang kemudian ditawarkan untuk menjadi dasar pengetahuan dalam kegiatan preservasi yang baru.

Adapun pada tahap kombinasi, telah terjadi sistematisasi konsep dalam berbagi pengetahuan. Teknologi informasi seperti grup komunikasi di media sosial sangat efektif dalam menyebarkan pengetahuan yang baru secara langsung dan menyeluruh. Tahap terakhir, ialah internalisasi, yakni proses pemahaman pengetahuan yang sebelumnya dimiliki pustakawan yang lalu diserap pustakawan lain melalui konsep belajar sekaligus mempraktikkan.

Pustakawan Sub Bidang Perawatan dan Perbaikan Bahan Pustaka memiliki berbagai cara dalam kegiatan berbagi pengetahuan. Hal ini sesuai penelitian Indra (2015) yang membahas mengenai perilaku berbagi pengetahuan pada Himpunan Mahasiswa Ilmu Informasi dan Perpustakaan (Himaka) Unpad. Menurutnya, telah terjadi kegiatan berbagi pengetahuan di HIMAKA dalam memperoleh pengetahuan, seperti komunikasi personal dan interpersonal, kelompok diskusi, belajar dan mengamati, baik dari pengalaman sendiri maupun dari lingkungan sekitar. Adapun Cara yang paling sering dilakukan secara langsung adalah melalui diskusi atau pertemuan secara tatap muka langsung. Begitu pun kegiatan proses berbagi pengetahuan di 
Sub Bidang Perawatan dan Perbaikan Bahan Pustaka Perpustakaan Nasional Republik Indonesia, sudah sesuai dengan 4 aspek berbagi pengetahuan, di antaranya aspek subjektif, aspek sikap, aspek pengontrol aspek perilaku, dan aspek jaringan sosial. Pertama, sesuai aspek norma subjektif. Pustakawan dalam aspek ini, mampu mengikuti dan menyikapi secara bersama-sama kebijakan baru dari atasan Kedua, pustakawan melalui sikap yang baik telah berhasil membawa arah perpustakaan ke arah yang makin baik sehingga tidak lagi monoton. Ketiga, perpustakaan dalam aspek pengontrol perilaku telah dapat memaksimalkan potensi para pustakawan dalam memberikan kebebasan berkarya di luar sub bidang. Terakhir, pustakawan pun dalam aspek jaringan sosial mampu menambah kemudahan dalam membagikan pengetahuan melalui grup di media sosial, seperti WhatsApp.

Pustakawan harus terlebih dahulu mengumpulkan pengetahuan sebanyakbanyaknya sebelum kegiatan berbagi pengetahuan dilakukan pada pustakawan lain. Setiap pustakawan dapat memperoleh pengetahuan dari mengikuti banyak kegiatan formal maupun informal. Pengetahuan berguna untuk menambah wawasan, membentuk pola pikir dan tentu saja perilaku. Para staf Sub Bidang Perawatan dan Perbaikan Bahan Pustaka Perpustakaan Nasional Republik Indonesia banyak memperoleh pengetahuan sebagai bekal melakukan pekerjaan para pustakawan dari pengalaman mengikuti berbagai kegiatan di perpustakaan maupun instansi lainnya. Hal ini diungkapkan narasumber.

“Di Perpusnas tuh pertama masuk bakal langsung ikut DIKLAT dulu, buat ngasih tau mereka bakal ngapain aja di Perpusnas ini. Terus, Perpusnas sering ngadain tu seminar kepustakawanan. Kita boleh ikut terutama tentang preservasi. Buat staf yang emang bagus track record-nya, mereka bisa tuh ngajuin beasiswa melanjutkan studi" (Vina, wawancara, July 13, 2018).

Setiap pustakawan di Perpustakaan Nasional Republik Indonesia diharapkan mengikuti pelatihan dan pengalaman selama bekerja sebagai bekal pengetahuan, agar mereka memiliki kemampuan bekerja secara profesional. Pustakawan pun harus mampu bekerja sama dalam organisasi, siap bekerja di bawah tekanan, dan bekerja sesuai harapan atau target dari pimpinan. Hal ini tidak hanya bermanfaat untuk pustakawan sendiri, namun juga bagi organisasi.

Seorang pustakawan dapat mengembangkan organisasi melalui berbagi pengetahuan di dalam organisasi, melalui komunikasi di saat mengobrol dan berdiskusi. Kegiatan ini dapat dimasukkan ke dalam interaksi social, di mana sebuah hubungan antara 2 individu atau lebih yang memberikan pola pikir, sikap, dan perilaku yang dapat memengaruhi, mengubah, atau memperbaiki individu lainnya. Berdasarkan hasil observasi peneliti, interaksi para pustakawan dapat dilakukan antar pustakawan dalam berbagai kondisi, misalnya ketika melakukan pekerjaan. Komunikasi dengan mengobrol dan berdiskusi biasanya dilakukan para staf ketika mulai jenuh saat mengerjakan pekerjaan atau ketika tidak terlalu sibuk. Begitu pula, ketika saat jam istirahat makan siang, para pustakawan cenderung lebih terbuka satu sama lain. Hal ini dimulai dari obrolan yang tidak 
begitu penting hingga membahas masalah yang berkaitan dengan pekerjaan.

Pustakawan melakukan berbagi pengetahuan di antara pustakawan secara individu dan secara kolektif dalam organisasi sub bidang tersebut. Proses berbagi pengetahuan kemudian diterapkan ke dalam kegiatan yang dilaksanakan Sub Bidang Perawatan dan Perbaikan Bahan Pustaka. Kegiatan ini dilakukan para pustakawan bersama Kepala Sub Bidang, dimulai dari rapat awal tahun dan akhir tahun. Selain itu, ada kegiatan yang bersifat insidental, yakni rapat evaluasi, tamu kunjungan dari luar perpustakaan, serta beberapa kegiatan lainnya.

Pustakawan di Sub Bidang Perawatan dan Perbaikan Bahan Pustaka, mempraktikkan pengetahuan saat melakukan pekerjaan sehari-hari. Proporsi pekerjaan yang ada di perpustakaan dilakukan setiap pustakawan sub bidang sesuai tugas pokok dan fungsi masingmasing pustakawan. Hal ini, tidak ada perbedaan antara pustakawan yang sudah lama dengan staf yang masih terhitung baru bergabung. Selain itu, tidak ada perbedaan pula antara pustakawan lakilaki dengan pustakawan perempuan.

Proses berbagi pengetahuan tidak hanya terlihat dari interaksi sesama pustakawan saja. Namun, pustakawan dengan perpustakaan memiliki kontribusi pengetahuan nyata secara timbal balik. Che, Wu, Wang, and Yang (2018) berkata, "Impacts of knowledge sourcing on employee innovation: the moderating effect of information transparency." Pengetahuan sering kali dikhususkan untuk setiap individu. Hal ini tidak mungkin bagi karyawan untuk melihat semua informasi yang tersedia, yang mengarah pada efisiensi yang rendah. Maka, pustakawan harus mampu menemukan pengetahuan yang relevan dan kredibel secara tepat.

Pengetahuan masing-masing pustakawan sebagian besar didapatkan melalui pendidikan formal dan pelatihan. Setelah itu, pustakawan memiliki pengetahuan mempraktikkan ilmu ini ke dalam pekerjaannya sehari-hari. Hal ini dibuktikan dengan masa aktif bekerja para individu, di mana paling muda adalah pustakawan yang baru bergabung kurang lebih dari 3 tahun lalu. Pustakawan tidak hanya sebatas mengaplikasikan pengetahuan yang dimilikinya, namun mereka sudah cukup mengerti mengenai kegiatan preservasi, mulai dari pekerjaan utama dan aktivitas yang berkaitan dengan preservasi. Pustakawan akan tetap dapat fokus bekerja walaupun posisi pustakawan berganti. Hal ini misalnya penggantian pustakawan pada kegiatan pemutihan bahan pustaka (bleaching) naskah kuno yang berganti menjadi deasidifikasi (penetralan asam kertas) basah atau kering.

Che et al. (2018) menambahkan bahwa, "Others' past performance may provide credible cues to locate experts so as to knowledge sources. If information transparency is high, individuals can know others' expertise." Sesuai rujukan ini, dijelaskan bahwa kinerja orang lain dapat dijadikan sebagai sumber pengetahuan. Jika transparansi informasi tinggi, maka seseorang dapat mengetahui keahlian orang lain juga. Transparansi informasi yang tinggi dapat membantu seseorang untuk menemukan pengetahuan orang lain, dan membantu menyaring pengetahuan tersebut. Hal ini sangat berguna untuk meningkatkan kredibilitas seseorang. 
Pengetahuan yang terus berkembang pada masing-masing individu membuat individu merasa penasaran terhadap hal baru yang belum pernah dipelajari. Begitu pula pada pustakawan Sub Bidang Perawatan dan Perbaikan Bahan Pustaka. Pustakawan memulai dari pengalaman masing-masing individu yang sudah diperoleh bertahun-tahun sehingga membuat para pustakawan terus berkembang, dan memiliki kepedulian untuk terus memperbaiki dan memaksimalkan lingkungan kerja. Ada juga pustakawan yang telah berhasil mengerjakan hal lain di luar bidang preservasi. Salah satunya ialah narasumber dari bagian Strategic Management Officer (SMO) Perpustakaan Nasional Republik Indonesia, sebagai perwakilan dari pusat preservasi.

Kegiatan perencanaan dan evaluasi menjadi kegiatan rutin dan penting sebagai sarana para pustakawan Sub Bidang Perawatan dan Perbaikan Bahan Pustaka dalam berbagi pengetahuan. Hal ini karena kegiatan perencanaan dan evaluasi menjadi kegiatan untuk berbagi informasi dan pengetahuan dari satu pustakawan pada pustakawan lain yang diadakan melalui rapat formal. Pada kegiatan tersebut, para pustakawan bercerita dan melaporkan apa saja yang sudah dilakukan selama berkegiatan. Selain itu, hal ini menjadi ingatan kembali dari kejadian penting yang sudah terjadi untuk kemudian direfleksikan dan dijadikan pelajaran untuk hari selanjutnya. Hal ini diungkapkan seorang narasumber.

"Kita kalo rapat secara formal biasanya cuma di awal sama akhir tahun. Awal tahun biasalah dipake buat perencanaan target jumlah koleksi yang diperbaiki, koleksi apa saja yang akan diperbaiki, pengadaan bahan. Akhir tahun kita evaluasi dari yang udah direncanain awal tahun dan laporan-laporan dari koordinator lapangan. Kalo evaluasi per-orang, saya di sini ngebebasin staf langsung buat evaluasi kalo ada yang misalnya gak suka sama cara kerjanya" (Rahma, wawancara, July 18, 2018).

Berdasarkan informasi tersebut menunjukkan bahwa ternyata diperlukan perencanaan dan evaluasi dalam setiap kegiatan yang hendak dilakukan, terutama kegiatan yang akan dilakukan secara terus-menerus. Hal ini diperlukan agar organisasi dapat mempunyai target secara jelas. Perencanaan dan evaluasi pun dapat digunakan untuk menentukan arah dan pola kebijakan yang tepat, termasuk tentang bagaimana berbagi pengetahuan memiliki peran yang lebih penting. Terlebih lagi dalam kegiatan berbagi pengetahuan, perencanaan dan evaluasi senantiasa dibutuhkan untuk mencegah salah paham (miss communication) antar anggota sub bidang tersebut.

Namun di balik pelaksanaan berbagi pengetahuan yang berjalan selama ini, ternyata masih ditemukan beberapa kendala yang dialami para pustakawan Sub Bidang Perawatan dan Perbaikan Bahan Pustaka. Hal tersebut diutarakan salah satu narasumber.

“Karena kemampuan daya ingat pengetahuan yang sifatnya teoretis emang setiap staf kan berbeda. Jadi ya, beberapa staf yang memang bisa dibilang kemampuan daya ingat itu kurang, otomatis pengetahuan yang dibagikan ke staf lainnya pun tidak akan maksimal semuanya. Belum lagi terkadang pemilihan kata atau bahasa yang digunakan terkadang sulit 
dipahami staf lain. Terlebih lagi pedoman yang ada pun kurang up to date sama keadaan sekarang jadi belum bisa menyeimbangkan dengan perkembangan pengetahuan preservasi saat ini" (Adit, wawancara, July 20, 2018).

Kendala lainnya adalah kurang tersedianya alat pengukur yang pasti dan ketetapan yang jelas. Pengalaman kerja sehari-hari banyak membantu mereka untuk terus mengingat pengetahuan, terutama untuk pekerjaan yang mereka sukai. Hal ini berakibat pada masingmasing pustakawan yang memiliki keahlian khusus. Hal ini diperkuat narasumber.

"Kalo kendala sih lebih ke yang sifatnya teknis sih, Mas. Kayak kalau di buku pedoman ada tuh ukuran atau takaran pasti bahan kimia yang kita pakai. Tapi kita lebih seringnya pake patokan sendiri karena kita gak punya alat pengukurnya itu" (David, wawancara, July 18, 2018)

Berdasarkan informasi tersebut, terlihat bahwa ketika melakukan pengukuran sesuatu, masing-masing pustakawan memiliki ketetapan ukuran sendiri. Hal ini berdampak pada hasil kerja yang berbeda-beda. Untuk itu, ketika melakukan suatu pekerjaan, harus ada spesialisasi pada masing-masing pustakawan sehingga pustakawan harus terbuka dengan pustakawan lain. Sesuai spesialisasi tersebut, para pustakawan akan lebih banyak membuka diri dengan pustakawan lainnya. Hal ini memang tidak mudah untuk membuka diri, namun perlu ada rasa percaya satu sama lain. Pustakawan yang sudah lama bekerja tidak sungkan untuk membuka diri dan mengajarkan kepada pustakawan yang lebih muda. Begitu pun, pustakawan yang lebih muda mau percaya dan terus belajar dari pustakawan yang sudah lebih lama bekerja.

Berdasarkan hasil observasi dan wawancara peneliti di lapangan, proses berbagi pengetahuan mempunyai beberapa faktor pendukung. Konsep berbagi pengetahuan sesuai objek, merupakan unsur penting yang tidak boleh tertinggal dalam menciptakan dan mengaplikasikan pengetahuan dalam sebuah organisasi. Seperti yang dijelaskan Smeaton and Davis (2014), bahwa penciptaan pengetahuan pada dasarnya dilakukan untuk menjaga keberlangsungan hidup suatu organisasi. Pustakawan memiliki pengetahuan yang berbentuk produk yang tidak berwujud, dapat berkembang secara luas dan sulit untuk dideskripsikan. Secara umum, pengetahuan tidak dapat kita lihat maupun kita raba. Akan tetapi, pengetahuan dapat kita rasakan, kita berusaha menangkap maknanya, dan kita peroleh dampaknya baik bagi diri kita sendiri dan orang lain. Pengetahuan dapat dijabarkan dan dikembangkan dalam bentuk langkah sistematis dan inovasi secara berkelanjutan.

$$
\text { Selain itu, perkembangan }
$$

pengetahuan sangat dipengaruhi inovasi. Berdasarkan inovasi yang terus berlangsung, maka mengaplikasikan pengetahuan baru akan sangat berpengaruh terhadap kreativitas pengembangan diri anggota organisasi dan organisasi itu sendiri secara terus menerus. Pengetahuan yang muncul dalam diri seseorang pun akan bertambah dan melahirkan pengetahuan yang baru pula. Hal ini berdampak baik bagi orang tersebut karena dapat mengembangkan 
diri tidak hanya di tempat ia bekerja namun juga dapat dikembangkan di mana pun ia berada.

Selain itu, tidak selamanya seseorang akan terus bekerja pada satu tempat yang sama. Tidak semua orang akan bertahan di tempat kerjanya. Ada kalanya merasa perlu mengembangkan karirnya lebih tinggi lagi atau sudah jenuh dengan lingkungan kerjanya. Maka ia dapat memutuskan untuk pindah ke tempat kerja yang baru. Selain itu, bertambahnya usia pada seseorang, suatu saat pasti akan membuatnya pensiun atau berhenti bekerja. Bagi lembaga atau organisasi yang menyadari kondisi seperti ini, berbagi pengetahuan menjadi pilihan tepat guna menyebarkan pengetahuan, arah, dan kebijakan yang ada kepada generasi penerusnya.

Proses berbagi pengetahuan perlu didasari rasa saling percaya antara satu dengan yang lainnya. Secara tidak langsung, berbagi pengetahuan sudah menjadi hal yang penting dalam melakukan pekerjaan sehari-hari. Berbagi pengetahuan tidak hanya dapat memberikan edukasi kepada orang lain mengenai pengetahuan baru. Namun juga menjadi solusi pemecahan masalah yang ada, dan menjadi bentuk kepedulian antar staf.

Keberlangsungan berbagi pengetahuan juga tidak lepas dari sejauh mana kesiapan diri dari masing-masing pustakawan tersebut. Mereka harus percaya pada pustakawan lain, dan memiliki kompetensi. Sesuai lingkungan dunia kerja di Indonesia, kompetensi diatur dalam Standar Kompetensi Kerja Nasional Indonesia (SKKNI) yakni rumusan kemampuan kerja yang mencakup aspek pengetahuan (knowledge), keterampilan/keahlian (skills) serta sikap kerja (attitude) yang relevan dengan pelaksanaan tugas dan syarat jabatan, ditetapkan sesuai dengan peraturan perundang-undangan yang berlaku.

Berdasarkan penjelasan tersebut, dapat ditarik kesimpulan bahwa kompetensi menjadi hal penting dalam sebuah ciri dasar perilaku dan kinerja individu. Hal ini menentukan kesiapan individu tersebut melakukan pekerjaan dengan baik, sesuai standar/kriteria yang telah ditentukan. Setiap pustakawan memiliki kompetensi masing-masing, di antaranya Kepala Sub Bidang, dan pustakawan lain yang sudah dapat dikatakan mahir sesuai bidangnya. Hal ini terlihat dari hasil wawancara narasumber.

"Di sini tuh semua staf paling minimal udah ikut diklat awal mereka masuk. Jadi gak ada tuh yang gak tau kondisi kerjaan kayak gimana. Alat-bahan semuanya udah dikasih tau" (Vina, wawancara, July 26, 2018).

Berdasarkan informasi tersebut, dapat dilihat bahwa pustakawan tingkat awal memiliki kompetensi yang sama. Semua pustakawan tidak ada perbedaan perlakuan, yang membedakan adalah hanya sejauh mana tingkat pemahaman dari masing-masing pustakawan tersebut. Secara keseluruhan, para pustakawan sudah mengetahui tugas, fungsi, dan peranan mereka masing-masing. Pengetahuan yang dibagikan pun akan mudah dimengerti karena masing-masing pustakawan mempunyai kompetensi yang kurang lebih setara. Tahap selanjutnya pengembangan kompetensi pustakawan yang sudah ada.

Namun dibalik faktor pendukung tersebut, terdapat faktor penghambat proses berbagi pengetahuan di sub bidang 
perawatan dan perbaikan bahan pustaka. Faktor pertama, ialah pustakawan belum sepenuhnya memahami pentingnya berbagi pengetahuan. Pustakawan yang lebih dulu bergabung belum sepenuhnya mau menerima inovasi yang coba diberikan pustakawan yang baru. Hanya beberapa pustakawan yang mau menerima ide baru tersebut, khususnya pustakawan yang masih terhitung baru bergabung. Mereka beranggapan bahwa ide baru yang ditawarkan akan membuat rumit pekerjaan yang ada.

Pustakawan yang baru bergabung pun masih terdapat ego untuk tidak membagikan seluruh pengetahuan yang dimiliki. Mereka cenderung angkuh dengan pengetahuan yang dimiliki. Mereka beranggapan bahwa pengetahuan yang mereka miliki lebih baru, jadi terkesan dapat mengatur pustakawan lainnya. Sampai saat ini, dalam struktur organisasi Perpustakaan Nasional Republik Indonesia, terutama bidang teknis preservasi. Pustakawan masih banyak yang tidak mengerti sedari awal mengenai penanganan teknis preservasi. Hal ini menjadikan pustakawan memerlukan waktu yang cukup lama untuk menyesuaikan dengan posisi yang baru ketika terjadi perubahan posisi. Mereka belum bisa melihat masalah dasar dalam preservasi sehingga berdampak pada kebijakan yang dikeluarkan perpustakaan menjadi kurang tepat sasaran.

Sub Bidang Perawatan dan Perbaikan Bahan Pustaka Perpustakaan Nasional Republik Indonesia akan tetap hadir dalam melakukan pembelajaran organisasi. Terkait dengan organisasi lain, Sub Bidang Perawatan dan Perbaikan Bahan Pustaka Perpustakaan Nasional
Republik Indonesia mempunyai satu rekan sub bidang yang masih berada dalam satu bidang yang sama, yakni Sub Bidang Teknis Penjilidan Bahan Pustaka. Sub bidang ini memiliki tugas dan peran dalam menjilid semua bahan pustaka yang telah dikerjakan oleh sub bidang lainnya. Ketika dua kepala sub bidang bertemu dalam satu forum, maka pengetahuan yang dibagikan akan berbeda. Hal ini berarti bahwa pengetahuan yang dimiliki Sub Bidang Perawatan dan Perbaikan Bahan Pustaka akan lebih kompleks.

Berdasarkan pengamatan peneliti yang dilakukan di Sub Bidang Perawatan dan Perbaikan Bahan Pustaka, maka terdapat alur atau skema dalam proses berbagi pengetahuan antar staf. Pada gambar 1 (daftar gambar) terdapat alur proses berbagi pengetahuan yang terdapat pada Sub Bidang Perawatan dan Perbaikan Bahan Pustaka Perpustakaan Nasional Republik Indonesia. Berdasarkan gambar ini, dapat dilihat bahwa proses berbagi pengetahuan dalam pembelajaran organisasi itu berlangsung terus menerus, tidak terputus. Pengetahuan para pustakawan didapatkan melalui bentuk kognitif melalui mengikuti berbagai kegiatan, seperti belajar melanjutkan pendidikan, tugas dinas, pelatihan, kunjungan, magang atau bentuk kegiatan lainnya. Pengetahuan tersebut kemudian disebarkan pada pustakawan lainnya melalui komunikasi, baik formal maupun informal. Adapun bentuk penyebaran dapat berupa pembuatan laporan kegiatan, rapat rutin atau insidental, mengobrol santai, atau kegiatan lainnya yang pada intinya akan menambah pengetahuan dan pemahaman para staf dalam menerima pengetahuan tersebut. 
Pengetahuan tersebut kemudian dilakukan uji coba berdasarkan kesiapan alat dan bahan, efisiensi waktu, dan kompetensi para pustakawan dalam kurun waktu tertentu. Setelah melalui penyesuaian dan diskusi lebih lanjut, maka pengetahuan ini menjadi sebuah pengalaman baru bagi para pustakawan untuk mencoba hasil pengetahuan mereka sendiri. Pustakawan di Sub Bidang Perawatan dan Perbaikan Bahan Pustaka memiliki beberapa dampak positif dalam proses berbagi pengetahuan yang selama ini dilakukan. Contoh dampak tersebut ialah masing-masing pustakawan dapat membuat pustakawan lain yang sebelumnya tidak mengetahui suatu informasi menjadi paham. Selain itu, pustakawan di sub bidang menjadi kuat dengan bekal pengetahuan yang dimiliki tiap individu.

Dampak selanjutnya adalah pustakawan lain yang sebelumnya tidak mengetahui suatu informasi dan mengerti bahwa terdapat informasi tersebut sebuah pengetahuan baru. Pustakawan mampu membagikan pengetahuan kepada pustakawan lain dengan jelas dan mudah dimengerti melalui interaksi dan komunikasi. Hal ini terjadi karena pengetahuan yang didapatkan pustakawan dapat dibagikan pada pustakawan lain. Pengetahuan baru ini, yang diharapkan dapat membuat para pustakawan semakin efektif dan efisien saat bekerja. Setelah itu, pustakawan memahami bahwa pengetahuan yang dibagikan menjadi milik bersama, tidak lagi milik pustakawan tertentu. Maka, pustakawan dapat memperbarui pengetahuan milik kelompok Sub Bidang Perawatan dan Perbaikan Bahan Pustaka Perpustakaan Nasional Republik
Indonesia. Adapun kinerja yang dihasilkan para pustakawan pun akan lebih baik lagi melalui pengetahuan baru tersebut.

\section{SIMPULAN}

Berdasarkan informasi pada pembahasan di atas, maka dapat disimpulkan bahwa pustakawan di Sub Bidang Perawatan dan Perbaikan Bahan Pustaka Perpustakaan Nasional Republik Indonesia sedang berkembang untuk selalu menjadi bagian dari usaha pelestarian koleksi bahan pustaka. Sub bidang ini sudah melakukan upaya berbagi pengetahuan dalam pekerjaan yang mereka jalani. Pengetahuan yang ada, tidak lagi menjadi milik satu pustakawan saja namun sudah menjadi milik bersama. Setiap pustakawan sudah memahami pentingnya berbagi pengetahuan. Namun pustakawan tidak menyadari bahwa mereka telah melakukannya dalam pekerjaan seharihari. Pustakawan yakin bahwa melalui berbagi pengetahuan dengan satu sama lain akan berdampak pada kemajuan bersama. Berbagi pengetahuan dapat membantu meringankan pekerjaan agar tidak terlalu rumit. Para pustakawan pun tidak memandang pengetahuan diperuntukkan untuk pustakawan tertentu, dan sikap yang tidak meremehkan untuk berbagi pengetahuan. Proses tersebut di antaranya aspek norma subjektif, sikap, aspek kontrol perilaku, dan aspek jaringan sosial. Pustakawan dalam norma subjektif, selalu menerima kebijakan yang baru dari atasan secara langsung di PERPUSNAS. Adapun dalam sikap, pustakawan telah berhasil membawa arah organisasi ke arah yang semakin baik dan tidak monoton. 
PERPUSNAS dalam aspek kontrol perilaku telah memaksimalkan potensi staf dengan memberikan kebebasan untuk berkarya di luar sub bidang. Selain itu, aspek jaringan sosial telah menambah kemudahan pustakawan ketika berbagi pengetahuan melalui grup media sosial, seperti WhatsApp. Untuk penelitian selanjutnya, peneliti akan mencoba meneliti kegiatan berbagi pengetahuan sebagai pembelajaran organisasi di Perpustakaan Sekolah Kolese Kanisius. Hal ini untuk melihat peran pustakawan sebagai agen perubahan perpustakaan.

\section{DAFTAR PUSTAKA}

Batubara, A. K. (2011). Urgensi kompetensi komunikasi pustakawan dalam memberikan layanan kepada pemustaka. Iqra': Jurnal Perpustakaan Dan Informasi, 5(1), 50-56. Retrieved from

http:/ / repository.uinsu.ac.id/643/1/ \%287\%29URGENSI KOMPETENSI KOMUNIKASI PUSTAKAWAN

DALAM MEMBERIKAN LAYANAN KEPADA PEMUSTAKA.pdf

Candrasari, S. (2019). Komunikasi interpersonal melalui penggunaan media sosial antara dokter dan pasien di Klinik Medika Lestari Jakarta. Jurnal Professional, 6(1), 32-41. Retrieved from

https://jurnal.unived.ac.id/index.php /prof/article/view/836/704

Che, T., Wu, Z., Wang, Y., \& Yang, R. (2018). Impacts of knowledge sourcing on employee innovation: The moderating effect of information transparency. Journal of Knowledge Management, 23(2), 221-239. https:/ / doi.org/10.1108/JKM-112017-0554
Dragicevic, N., Ullrich, A., Tsui, E., \& Gronau, N. (2019). A conceptual model of knowledge dynamics in the industry 4.0 smart grid scenario. Knowledge Management Research and Practice, 17(3), 1-15. https://doi.org/10.1080/14778238.201 9.1633893

Indra, M. A. (2015). Perilaku knowledge sharing pada Depatemen Media Himpunan Mahasiswa Ilmu Informasi dan Perpustakaan (Himaka) Fakultas Ilmu Komunikasi (Fikom) Universitas Padjadjaran (Unpad) (Skripsi) (Universitas Padjadjaran, Sumedang). Retrieved from http:/ / webcache.googleusercontent.c om/search?q=cache:nXO2Kv7_U6sJ:li brary.fikom.unpad.ac.id/digilib/gdl.p hp\%3Fmod\%3Dbrowse\%26op\%3Drea d\%26id\%3Djbptunpadfikom-gdlmuhammadal$7401+\& \mathrm{~cd}=1 \& \mathrm{hl}=\mathrm{id} \& \mathrm{ct}=\mathrm{clnk} \& \mathrm{gl}=\mathrm{id}$

Kementerian Pendidikan dan Kebudayaan. Undang-Undang Republik Indonesia nomor 43 tahun 2007 tentang perpustakaan. , Pub. L. No. 43 (2007).

Nonaka, I., \& Takeuchi, H. (1995). The knowledge-creating company: How Japanese companies create the dynamics of innovation. Retrieved from https://scholar.google.com/scholar_1 ookup?title=The knowledge-creating company\&author=I.

Nonaka\&author $=\mathrm{H}$.

Takeuchi\&publication_year=1995

Prabowo, T. T. (2016). Implementasi manajemen pengetahuan di Perpustakaan UIN Sunan Kalijaga Yogyakarta. Kajian Informasi $\mathcal{E}$ Perpustakaan, 4(2), 10.24198/jkip.v4i2.9970. https://doi.org/10.24198/jkip.v4i2.99 
70

Smeaton, K., \& Davis, K. (2014). Using social media to create a participatory library service: An Australian study. Library and Information Research, 38(117), 54-76. https:/ / doi.org/10.29173/lirg593

Tumanggor, P. S. M. (2018). Penerapan label berwarna dalam proses shelving koleksi mancanegara pada Perpustakaan Nasional RI (Laporan Akhir D-III) (Universitas Sumatera Utara, Medan). Retrieved from

http:/ / repositori.usu.ac.id/bitstream/ handle/123456789/13269/152201028.p $\mathrm{df}$ ?sequence $=1$ \&isAllowed $=\mathrm{y}$

Wardiana, D., Khadijah, U. L. S., \& Rukmana, E. N. (2018). Dokumentasi budaya ngaruat lembur di Radio RASI FM. Kajian Informasi $\mathcal{E}$ Perpustakaan, 6(1), 43-58. https://doi.org/10.24198/jkip.v6i1.15 325 


\section{DAFTAR GAMBAR}

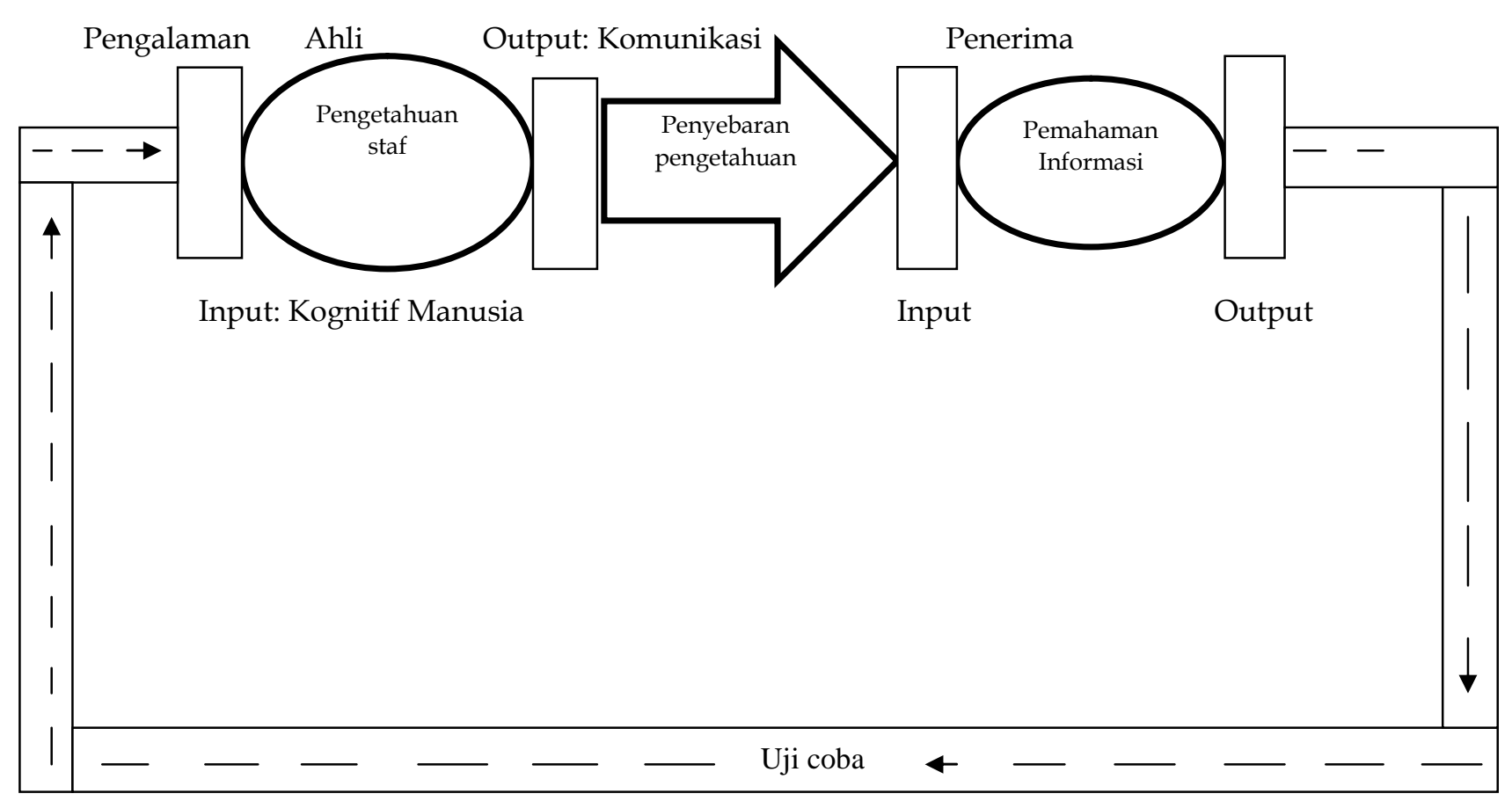

Gambar 1. Proses berbagi pengetahuan dalam pembelajaran organisasi Sumber: Adaptasi penulis dari berbagai sumber rujukan, 2018 
